|| ISSN(online): 2589-8698 || ISSN(print): 2589-868X || International Journal of Medical and Biomedical Studies

Available Online at www.ijmbs.info

PubMed (National Library of Medicine ID: 101738825)

Index Copernicus Value 2018: 75.71

Original Research Article

Volume 3, Issue 6; June: 2019; Page No. 58-60

\title{
SUBSTANCE ABUSE AMONG IMMIGRANT CONSTRUCTION WORKERS
}

\author{
Dr. Rattiram Meena ${ }^{1}$, Dr. Rekha Acharya ${ }^{2}$, Dr. Aarti Acharya ${ }^{2}$, \\ ${ }^{1}$ Medical Officer, ${ }^{2}$ Professor and HOD, ${ }^{3}$ Senior Demonstrator, \\ ${ }^{1-3}$ Department of Preventive and Social Medicine, Sardar Patel Medical College, Bikaner.
}

Article Info: Received 17 April 2019; Accepted 05 June. 2019

DOI: https://doi.org/10.32553/ijmbs.v3i6.295

Address for Correspondence: Dr. Rekha Acharya, Professor and HOD, Department of Preventive and Social Medicine, Sardar Patel Medical College, Bikaner.

Conflict of interest: No conflict of interest.

\begin{abstract}
Background: Substance abuse can simply be defined as a pattern of harmful use of any substance for moodaltering purposes. "Substances" can include alcohol and other drugs (illegal or not) as well as some substances that are not drugs at all.

Methods: This cross sectional study was conducted among the migrant workers working in Bikaner Rajasthan, over the time duration of 3 months. All migrant laborers above the age group of 18 years were included in the study. Data was collected from ante-natal register using Predesigned, pretested, validated and structured proforma.

Result: In our study prevalence of substance abuse was found to be among $84.00 \%$ of participants. $44.8 \%$ of the study participants were consuming alcohol, $50.2 \%$ of the study participants were chewing tobacco.

Conclusion: The result of the present study suggests that substance abuse among migrant workers was very high. Policy makers must pay extra attention to the health of migrants by implementing safety measures and organizing intense behaviour change communication.
\end{abstract}

Keywords: Alcohol, Smoking, immigrant construction workers

\section{Introduction:}

Substance abuse can simply be defined as a pattern of harmful use of any substance for mood-altering purposes. "Substances" can include alcohol and other drugs (illegal or not) as well as some substances that are not drugs at all ${ }^{1}$.

The epidemic of substance abuse among migrant workers has taken up alarming dimensions in India. This inclination towards substance abuse is most likely due to changing cultural values, increasing economic stress and dwindling supportive bonds ${ }^{2}$.

There are an estimated one billion migrants in the world today of whom 214 million international migrants and $\mathbf{7 4 0}$ million internal migrants. Migrant workers contribute significantly to the informal or unorganized sector of occupation. As per the NSSO (National Sample Survey Organization) report, 30 million workers in India are migrant workers. The health of migrants and health associated with migration are crucial public health challenges faced by governments and societies ${ }^{3}$

Drug use disorders are associated with substantial burden through impairment in major life roles and increased risk for suicidality, neuropsychological deficits, diminished quality of life, and infectious disease (eg, human immunodeficiency virus and hepatitis). Drug use disorders also confer substantial burden on families, social networks, and society as a whole through violent and property crime, incarceration, poverty, and homelessness. Changing societal factors in the last 15 years suggest changes in the distribution of DUDs in the adult population. These include public attitudes that have become increasingly permissive toward some types of drug use and legalization. Also prescriptions for opioid analgesics and other psychoactive medications with 
addiction potential have increased greatly, with consequences such as drug overdoses ${ }^{4}$.

\section{Material and methods}

This cross sectional study was conducted among the migrant workers working in Bikaner Rajasthan. All migrant laborers above the age group of 18 years were included in the study. Laborers who didn't give consent for the study were excluded from the study. The study was conducted after getting informed consent from all the participants. Data was analysed using the SPSS version 21 software. Descriptive statistics were reported as mean (SD) for continuous variables and frequency (percentage) for categorical variables. Pearson's Chi-square test was used to find association between two categorical variables. A $p$ value $<0.05$ was considered as statistically significant.

\section{Result}

Table 1: Socio-demographic profile of Study Population $(\mathrm{N}=500)$

\begin{tabular}{|l|l|l|}
\hline Variables & Frequency & Percentage \\
\hline Age & & \\
\hline Below 20 & 52 & 10.4 \\
\hline 20 to 39 & 305 & 61.00 \\
\hline Above 40 & 143 & 28.6 \\
\hline Sex & & \\
\hline Male & 464 & 93.8 \\
\hline Female & 36 & 7.2 \\
\hline Educational status & & \\
\hline No formal schooling (Illiterate) & 112 & 22.4 \\
\hline Up to primary schooling & 184 & 36.8 \\
\hline Up to Secondary schooling & 200 & 40.00 \\
\hline College/University completed & 4 & 0.8 \\
\hline Marital status & & \\
\hline Married & 324 & 64.8 \\
\hline Unmarried & 176 & 35.2 \\
\hline Religion & & \\
\hline Hindu & 428 & 85.6 \\
\hline Muslim & 72 & 14.4 \\
\hline Type of Family & & \\
\hline Nuclear & 42 & 8.4 \\
\hline Joint & 448 & 91.6 \\
\hline
\end{tabular}

Table 1 shows the Distribution of Study Population by Age and Gender, The age of the participants varied from 20-40 years, with mean of $27.62 \pm 7.65$ years; among them $93.8 \%$ were males and $7.2 \%$ were females. Among the study Population $64.8 \%$ of the participants were married and $85.6 \%$ belonged to Hindu religion. $91.6 \%$ of the study participants lived in a joint type of family.

Table 2: Distribution of study population based on various type opf substance abuse $(\mathrm{N}=500)$

\begin{tabular}{|l|l|l|}
\hline Variables & Frequency & Percentage (\%) \\
\hline Type & & \\
Alcohol & 224 & 44.8 \\
Cannabis & 2 & 0.4 \\
Opiods & 2 & 0.4 \\
Smoking & 251 & 50.2 \\
Tobacco Chewing & 184 & 36.8 \\
Others & 5 & 1.0 \\
\hline
\end{tabular}


Table 2 shows the pattern of substance abuse among the migrant workers, where majority that is $44.8 \%$ of the study participants were consuming alcohol, $36.8 \%$ of the study participants were chewing tobacco and $50.2 \%$ were smoking.

\section{Discussion}

Present study was conducted among 500 migrant workers individuals, Prevalence of substance abuse was found to be among $84.00 \%$ of participants.

The age of the participants varied from $20-40$ years, with mean of $27.62 \pm 7.65$ years. In a study conducted by Laad PS etal ${ }^{5,}$ Akram S etal ${ }^{6}$ and Parashar $M$ etal ${ }^{7}$ age of the study participants were 27 years, 21 years, 32 years respectively. In our study majority of the participants studied till secondary level. While in the study done by Laad PS eta ${ }^{5}$ majority of the participants were not literate.

In our study the pattern of substance abuse among the migrant workers was found to be as follows. Majority that is $44 \%$ of the study participants were consuming alcohol, $36.8 \%$ of the study participants were chewing tobacco. Around $50.2 \%$ were smoking. Akram S etal ${ }^{6}$ in his study found that overall tobacco usage was found to be $53.7 \%$ and majority of the participants reported to use chewing $(41.8 \%)$ and smoking form of tobacco(11.9\%).

\section{Conclusion}

The result of the present study suggests that substance abuse among migrant workers was very high. Policy makers must pay extra attention to the health of migrants by implementing safety measures and organizing intense behaviour change communication.

\section{References}

1. WHO. Techn. Res. Ser. No.886: 1999. p. 48. [last accessed on 28 sep 2018]. Available at http://www.who.int/biologicals/technical_repor t_series/en/

2. Swendsen JD, Merikangas KR. The comorbidity of depression and substance use disorders. Clin Psychol Rev. 2000;20(2):173-189

3. WHO-Migrants Health. [last accessed on $28 \mathrm{sep}$ 2018]. Available from http://www.who.int/hac/ techguidance/health_of_migrants/en

4. Volkow ND, Baler RD, Compton WM, Weiss SR. Adverse health effects of marijuana use. N Engl J Med. 2014;370(23):2219-2227.

5. Laad PS, Adsul BB, Chaturvedi RM, Shaikh M. Prevalence of Substance Abuse among Construction Workers. PARIPEX - INDIAN JOURNAL OF RESEARCH 2013;2(3):280-83.

6. Akram S, Gururaj NA, Nirgude AS, Shetty S. A Study on Tobacco use and Nicotine Depen-dence among Plywood Industry Workers in Mangalore City. Journal of Evolution of Medical and Dental Sciences 2015; 4(33):5729-35

7. Parashar $M$, Agarwalla $R$, Mallik $P$, Dwivedi $S$, Patvagekar B, Pathak R. Prevalence and correlates of nicotine dependence among construction site workers: A cross sectional study in Delhi. Lung India 2016;33:496-501. 